\title{
Chica que manda ou a Mulher que inventou o mar? ${ }^{1}$
}

\author{
Conceição Evaristo* \\ Universidade Federal de Minas Gerais
}

\begin{abstract}
Resumo: Percorrendo os registros da história oficial brasileira, observase a ausência de relatos que destaquem a atuação das mulheres negras em vários episódios de nossa história nacional. Caso singular é o de Francisca da Silva de Oliveira que, ao atingir o status de "objeto histórico", se torna, entretanto, vítima de uma narrativa profundamente estereotipada. Os primeiros relatos históricos sobre Chica da Silva, determinados sempre por uma ótica masculina e branca, aparecem reeditados pelas produções literárias, cinematográfica e televisiva que, ao longo do tempo, vão surgindo sobre essa personagem negra, que marcou a história de Minas Gerais e do Brasil Colônia. O presente ensaio
\end{abstract}

\footnotetext{
${ }^{1} \mathrm{O}$ título do presente artigo se refere às obras de VASCONCELOS, Agripa. Chica que manda. Belo Horizonte: Itatiaia, 1966 e de VIEIRA, Lia. Chica da Silva - a mulher que inventou o mar. Rio de Janeiro: OR Produtor Editorial Independente, 2001.

* Doutora em Literatura Comparada pela Universidade Federal Fluminense. Em sua pesquisa de tese, estudou as relaçóes entre a literatura afro-brasileira e as literaturas africanas de língua portuguesa. Participante ativa dos movimentos de valorização da cultura negra no país, estreou na literatura em 1990, quando passou a publicar seus contos e poemas na série Cadernos Negros. Publicou Ponciá Vicêncio (romance, 2003); Becos da Memória (romance, 2006; Poemas da recordação e outros movimentos (2008); Insubmissas lágrimas de mulheres (contos, 2011).
}

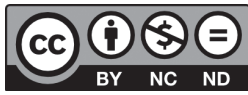

Esta obra está licenciada sob uma Licença Creative Commons. 
traz algumas considerações em torno da criação e da recriação da imagem de Chica da Silva tendo por base textos históricos e literários. Pode-se afirmar que há certa coerência entre a representação histórica e a literária. Em ambas as modalidades, na maioria das vezes, impera um imaginário em que a mulher negra seria sedutora somente pelos seus dotes físicos sexuais. E para cotejar com as diversas versóes criadas sobre Chica da Silva, trouxe para leitura o texto ficcional afro-brasileiro, Chica da Silva - a mulher que inventou o mar, de autoria de Lia Viera, buscando apreender distanciamentos e/ou aproximaçóes da criação afro-brasileira com as narrativas anteriores a respeito de Francisca da Silva de Oliveira.

Palavras-chave: História. Literatura. Representação. Mulher Negra.

\section{Introduçáo}

Vítima de invisibilidade por parte do registro histórico brasileiro, a mulher, em geral, é concebida a partir de uma representação estática, que projeta uma "enfadada ilusão de imobilidade" de sua pessoa, conforme argumenta Mary Del Priore (1994, p. 11). A autora observa que tanto a mulher da elite como a do povo são representadas a partir de estereótipos na história do Brasil. A primeira aparece "auto-sacrificada, submissa sexual, material e reclusa com rigor”. À imagem dessa mulher se contrapóe a da segunda, que aparece como promíscua, lasciva, "pivô da miscigenação e das relaçóes interétnicas que justificaram por tanto tempo a falsa cordialidade entre colonizadores e colonizados" (ibid). Nesse sentido é preciso enfatizar que se na História do Brasil há pouquíssimos registros sobre a mulher branca como agente da nacionalidade brasileira, para as mulheres negras, todo e qualquer protagonismo, experimentado pelas africanas e suas descendentes no Brasil, sofreu um apagamento histórico.

$\mathrm{O}$ tratamento dado pelos historiadores à saga dos africanos e seus descendentes, no Brasil, só começou a apresentar algumas mudanças, na década de 80 , período de grande efervescência dos movimentos sociais. A aproximação do Centenário da assinatura da Lei Áurea, em 1988, 
aprofundou não só as demandas do Movimento Negro, como também gerou novas proposiçôes para a escrita e para a compreensão da História do Brasil. Surgiram vários textos cujo foco principal incidia sobre a escravizaçáo africana e as lutas quilombolas empreendidas pelos sujeitos escravizados em busca de liberdade. Obras literárias, principalmente as de autoria afro-brasileira, buscavam apresentar heróis negros da história como motivo de inspiração poética. O nome de um herói sobressaiu: o de Zumbi de Palmares.

Observa-se, porém, que, mesmo nesse período, pouquíssimas referências foram feitas às heroínas negras. Coube principalmente ao Movimento de Mulheres Negras o resgate de nomes como o de Nzinga, ${ }^{2}$ Acotirene, ${ }^{3}$ Dandara, ${ }^{4}$ que passaram a nomear as próprias organizaçôes de mulheres negras. Foi, também nessa década, a publicação de um belo poema, em homenagem a Luiza Mahin, ${ }^{5}$ de autoria de Miriam Alves (1986, p. 46), em Cadernos Negros, do Grupo Quilombhoje Literatura de São Paulo, ${ }^{6}$ cujo título é "Mahin Amanhâ".

No poema, Alves confere a Luiza Mahin um papel histórico como liderança maior na Revolta dos Malês, uma insurreiçấo de africanos escravizados, que ocorreu em 1835 na Bahia. Primorosamente construída, a arquitetura do poema em si sugere a ideia de movimento. Procedimentos estilísticos, como a repetição e a colocaçáo dessimétrica de determinados versos, o jogo fônico com a aproximação gráfica e o recurso de recorte e colagem das palavras "Mahin" e "amanhâ", a nomeação de grupos étnicos africanos transportados para o Brasil, a

${ }^{2}$ Heroína africana, Rainha de Ndongo, que, durante 40 anos, lutou contra a invasão portuguesa e contra o tráfico de escravos, no território que hoje é Angola.

${ }^{3}$ Matriarca de Palmares, líder quilombola de um dos mocambos que compunha o Quilombo Palmarino.

${ }^{4}$ Líder quilombola, criada em Palmares, que enfrentou as forças escravocratas portuguesas, ao lado de Zumbi de Palmares, sendo morta, na batalha final, com a destruição de Palmares.

${ }^{5}$ Luiza Mahin, africana livre, apontada como uma das lideranças da Revolta dos Malês, em 1835, na Bahia.

${ }^{6}$ Coletivo de escritores/as afro-brasileiros/as que, desde 1978, é responsável pela organização e publicação anual de Cadernos Negros, alternando, a cada publicação, poesia e prosa. As publicaçóes são autofinanciadas pelos próprios/as autores/as. 
descrição física da ambiência e dos envolvidos na cena - tudo confere uma ideia de movimento e produz o efeito de construir a imagem de uma mulher como força geradora desse movimento. No centro da trama poética, a imagem dessa mulher, ou melhor, a voz dela, correndo de um verso a outro, propaga e conclama a luta.

É preciso ressaltar, porém, que continuam praticamente inexistentes informações históricas precisas sobre Luiza Mahin. O que nos chegou sobre ela são preservaçóes de relatos orais e uma enfática afirmativa do poeta Luís Gama que, pronunciando-se filho de Mahin, diz:

[...] Sou filho natural de uma negra, africana livre, da Costa Mina (Nagô de Nação), de nome Luiza Mahin, pagã que sempre recusou o batismo e a doutrina cristá.

Minha mãe era baixa de estatura, magra, bonita, a cor era de um preto retinto

[...] muito altiva, geniosa, insofrida e vingativa.

Dava-se ao comércio - era quitandeira, muito laboriosa, e mais de uma vez, na Bahia, foi presa como suspeita de envolver-se em planos de insurreiçóes de escravos, que não tiveram efeitos. (GAMA, 2011, p. 131)

Entretanto, se a heroína Luiza não encontrou lugar nas páginas da história oficial, foi acolhida nas páginas da literatura. A escritora Ana Maria Gonçalves (2006), após uma exaustiva pesquisa, afirma não ter conseguido nenhum documento que comprovasse a existência histórica de Mahin, contudo, inspirada nos vários materiais que colheu, criou uma bela ficção sobre a mãe de Luís Gama, Luiza Mahin, escrevendo um romance com esse desconcertante título: Um defeito de cor.

Creio que essa breve introdução confirme o descaso com relação ao registro da saga dos africanos e seus descendentes no Brasil e aponte para a profunda invisibilidade que pesa sobre as mulheres negras, enquanto protagonistas de uma história brasileira. Entretanto, 
o nome de uma mulher negra é pronunciado na história nacional: Chica da Silva.

\section{Chica-que-manda ou a mulher que inventou o mar?}

Um exemplo bastante elucidativo do modo como se deu a representaçáo da mulher negra na historiografia brasileira se relaciona à construção da imagem de Chica da Silva. Observando uma obra que funde história e ficção, como o Romanceiro da Inconfidência, de Cecília Meireles (1975, p. 65), nos versos, pode ser apreendido o imaginário que pesava sobre Chica da Silva. Desapontados os velhos dizem: "Ainda vai chegar o dia/de nos vieram perguntar:/ - Quem foi a Chica da Silva/ que viveu neste lugar [...]". Enquanto lamentavam a desgraça que pairava sobre o Arraial do Tejuco, condenavam a lembrança de Chica da Silva ao esquecimento, pois que "(tudo passa.../O prazer é um intervalo/ na desgraça...)", e seguiam esconjurando a presença de Chica da Silva, desejando se verem livres da presença e da lembrança dela. No tempo tudo passa, pensavam e diziam os velhos, certos de que "se o vento dá no Tejuco/leva coluna e varanda,/leva a pompa, leva o luxo/e mais a Chicaque-manda" (MEIRELES, 1975, p. 65). A presença de Chica da Silva tinha sido tăo marcante e incômoda que se tornava necessário prever o seu esquecimento, contudo, sua história ficou: deturpada, mas ficou.

No interior do poema narrativo de Meireles, composto em 1953, Chica da Silva surge segundo os modelos consagrados pela História e pela ficção. São realçados os traços de uma Chica banhada em ouro, escrava alforriada, nas terras da Capitânia das Gerais, pelo contratador de diamantes, João Fernandes. A negra, que se postava feito a Rainha de Sabá, assemelhava-se a uma princesa núbia e tinha um estilo tão faustoso que, por ocasião das festas religiosas, chegava a ofuscar a própria Ifigênia Santa Negra, como indicam os versos "Nem Santa Ifigênia/toda em festa acesa/brilha mais que a negra/na sua riqueza.", mas que "(Por baixo $d a$ cabeleiraltinha a cabeça rapadale até dizem que era feia,) (p. 53). Há 
sempre a descrição da "Chica-que-manda", daquela que "em tanque de assombro [faz] velejar o navio, pois é a "dona do dono", do fidalgo João Fernandes, desejado por muitas (p. 55). Na reiterada afirmativa do poder de Chica, outras mulheres são exortadas a contemplar o poderio dela: "contemplai, branquinhas, /na sua varanda/ Chica da Silva/ a Chica-que-manda!" (p. 56). É ainda essa Chica, reconhecida por sua inteligência, por sua sagacidade e, mais do que isso, por sua capacidade de ser cúmplice do homem amado. Ela alerta João Fernandes para os perigos em volta, quando o Conde de Valadares, arruinado em seus bens, procura por interesses, o contratador. Chica da Silva diz: “- Eu nesse Conde não creio/ (...) detrás de suas palavras,/anda algum sentido oculto./Os homens, à luz do dia,/olham bem, mas não vêem muito:/" e como mulher que reconhece em si a capacidade de ver além das aparências, a partir mesmo do lugar que ela experimenta, diz: "dentro de quatro paredes,/as mulheres sabem tudo" (MEIRELES, 1975, p. 59).

Embora Chica da Silva, talvez mais do que outras mulheres, apareça transcrita em várias narrativas brasileiras, a sua entronização no panteão da pátria, podemos dizer, se dá de uma forma "suspeita". O primeiro registro sobre ela aparece no livro Memórias do Distrito Diamantino, escrito por Joaquim Felício dos Santos, em 1868. Sua condição de exescrava nunca foi esquecida, como também as suas características étnicas sempre causaram estranhamento. Felício dos Santos escreve que Chica da Silva é "de feições grosseiras, alta, corpulenta, não possuía graças, não possuía atrativos algum que pudessem justificar uma forte paixão" (SANTOS, 1978, p. 161).

Júnia Ferreira Furtado (2003) discute a maneira como Chica da Silva aparece retratada pela primeira vez na história. Para a historiadora, o relato histórico sobre Chica da Silva não consegue colocá-la no panteão dos heróis nacionais e aparece eivado pelo olhar preconceituoso da época. $\mathrm{O}$ autor, vivendo no século XIX, escreve os acontecimentos orientado por uma visão de mulher e família enquadradas na moral cristã e sob os efeitos dos preconceitos contra os ex-escravos, mulheres de cor e unióes consensuais (p. 266). Tanto a história, como os discursos ficcionais sobre 
a ex-escrava, surgidos ao longo do tempo, "criaram novos estereótipos, descrevendo uma Chica distante da mulher de carne e osso que viveu no arraial do Tejuco, dos anos 30 a 90 do século XVIII", afirma Junia Furtado (p. 284).

Outra obra, também na área da história, escrita em 1896, distingue, em meio a uma série de acontecimentos, a figura de Chica da Silva. Escrita pelo bispo de Mariana, Joaquim Silvério de Souza, o livro Sitios e personagens históricas de Minas Gerais (1988) não se apresenta menos preconceituoso em relação à Chica da Silva. Sob esse aspecto, Junia Furtado, em obra citada anteriormente, informa a divulgação do apelido de Chica no livro do religioso. A escrita de um representante da igreja aponta Francisca da Silva de Oliveira, como sendo: Chica "Quemanda" (FURTADO, 2003, p. 270). O livro desse representante do poder clerical repetia e propagava, em documento, uma alcunha carregada de ironia, de deboche, de despeito, enfim, uma designação reveladora do mal-estar que Chica da Silva causava à sociedade da época. Podemos concluir que a atribuição desse apelido a Chica, uma mulher que na sua origem trazia o estigma da escravidão, da subserviência, da obediência que deveria ser cumprida, informava, por si só, a reviravolta, a inversão de papéis, a subversão, o deslocamento de lugares, efetuado por Dona Francisca da Silva Oliveira. De escrava a senhora.

Há diversas obras de cunho histórico em que Chica da Silva aparece retratada como figura de destaque do período colonial brasileiro. Autores movidos pelos mais diversos motivos, desde uma reconstrução da memória da cidade de Diamantina a interesses turísticos, debruçaram-se sobre documentos escritos, relatos orais, obras anteriormente publicadas sobre Chica da Silva, na tentativa de descrever essa mulher que, saindo da senzala. intrometeu-se na casa-grande, onde não foi aceita, apenas tolerada. ${ }^{7}$ Um aspeto interessante a observar é a dificuldade dos relatos em precisar o típico físico de Chica da Silva. Ora ela é descrita como negra, ora como mulata clara, ora escura e mesmo morena, mas em todas imperam o imaginário sobre a sexualidade exacerbada das pessoas negras,

${ }_{7}^{7}$ Conferir autores como: Joaquim Silvério de Souza, Aires da Mata Machado Filho, Lucia Machado de Almeida, Soter Couto, dentre outros. 
notadamente das mulheres. Essa afirmativa pode ser conferida, por exemplo, no livro de Agripa Vasconcelos (1966). A obra, situada entre história e ficção, concebe a relação de Chica da Silva com o contratador João Fernandes, como um par romântico. Entretanto "o mito do fogo" entre as pernas, conferido às mulheres negras, se faz presente na descrição que o autor faz de Chica da Silva.

Celeiro e Nascimento (2011), lendo Agripa Vasconcelos, tecem as seguintes consideraçóes sobre a descriçấo física de Chica da Silva na obra. Em Vasconcelos, afirmam os dois estudiosos, Chica da Silva se acha intercalada "cromaticamte" entre preta e branca, sendo uma autêntica mulata. E, como tal, guardaria traços que distinguem a cor branca, contudo 'com o acréscimo desta pontinha de fogo, dessa lascívia atraente que dá o sangue negro'. (CELEIRO; NASCIMENTO, 2011, p. 227)

O mito de Chica da Silva, extrapolando os limites da história, amplia-se até o terreno da ficção. Romances, novela, filme, peça teatral, enredo de escola de samba, vão sendo elaborados ao longo do tempo, influenciados por informaçóes históricas, cuja origem se encontra no texto de Joaquim Felício dos Santos.

Várias consideraçôes podem ser feitas a respeito da produção ficcional sobre Chica da Silva. Abrimos este tópico comentando sobre a filiação de "Chica da Silva", a Chica-que-manda do Romanceiro da Inconfidência, aos textos históricos anteriormente escritos sobre ela. Entretanto, pretendendo romper com as narrativas históricas sobre Chica da Silva, em 1990, surge o livro Rei Branco, Rainha Negra de Paulo Amador (1990), que se inscreve nas narrativas que aspiraram resgatar, de forma positiva, o mito de Chica da Silva. Na estrutura do livro, um narrador onisciente, a personagem que encarna Padre Rolim, um dos participantes da Inconfidência Mineira, membro pertencente à família que criou Chica da Silva, decide "contar a verdadeira história de Chica da Silva" (p. 13). Alguém, pois da casa-grande, representante do poder religioso, tem autoridade/autoria para contar a história de Chica da Silva. Conveniente observar que, na biografia de Francisca da Silva Oliveira, consta que uma de suas filhas foi violentada por esse mesmo 144 
Padre Rolim. Embora destaque a inteligência e a vivacidade de Chica da Silva, há uma ênfase em sua descriçáo física e em sua sensualidade. Para comprovar essa afirmativa, basta observar a cena em que se descreve o desejo que Chica da Silva sente por João Fernandes:

João tocou no braço de Chica. A pele dela fervia. Chica olhou firme para Joáo. [...] Chica não encontrava palavra de língua de branco para dizer. Tudo que a partir dali chegava à ponta de sua língua era uma vontade desrespeitosa de falar em lingua de africano. $\mathrm{O}$ que fervia dentro dela, saía pela noite da pele, furava os panos de vestido, entrava no nariz de João Fernandes.

[...] João Fernandes foi até a porta, deu ordem ao feitor:

-Cabeça, não recebo ninguém no dia de hoje.

Fechou a porta. E Chica já se despia dos panos brancos de sua roupa africana. (p. 87 , grifos meus)

Essas e outras falas do narrador permitem localizar estereótipos comuns na composição da personagem tanto nas narrativas históricas como nas ficcionais. O texto cinematográfico de Cacá Diegues (1976) e o televisivo de Walcyr Carrasco (1996) também repetem e criam novos estereótipos, o que nos reporta a uma afirmação de Alberto Baeta Musa (1989, p. 72). Para Musa, os estereótipos são renovados e ressemantizados em seu processo de perpetuação sobre determinados indivíduos. $\mathrm{O}$ autor, retomando a Carta de Caminha, relembra a interpretação dada, pelos portugueses, à cultura ameríndia, pelo fato de os sujeitos indígenas não usarem roupas. A descrição de que as índias andavam com as "vergonhas" de fora, tinha por base uma interpretação europeia imposta a um significante ameríndio. Musa aponta o retorno modificado da imagem da índia nua no Modernismo. O estereótipo tradicional, o da nudez, o do despudor das mulheres indígenas, por andarem com "a vergonha de fora", ganha um valor positivo. Nudez, despudor é "bom”, não é mais "ruim"; "bonito", não "feio" Entretanto a ideia de estranhamento continua, o outro perdura no tempo e no espaço como sujeito ex-ótico. Parece-me que esse estranhamento, esse exotismo acompanham a imagem de Chica da Silva em sua descrição histórica e 
ficcional ao longo do tempo, uma sensualidade permissiva está sempre colada a sua imagem.

Paulo Amador evidencia a pretensão de reescrever a história de Chica da Silva desde a capa. Logo abaixo do título aparece uma longa frase interrogativa, como subtítulo: "Seria mesmo Chica da Silva a devoradora de homens que tirava a calma das famílias do velho Tejuco?" Ora, por essa inscrição interrogativa da capa, da edição de 1990, pode-se aferir que a intenção da narrativa nasce de um lugar comum. $\mathrm{O}$ mote para o desenvolvimento da história seria a licenciosidade de Chica. Ao longo da narrativa, o escritor apresenta personagens inteligentes, curiosas, participativas e que se norteiam por ideais de liberdade e igualdade, comprometendo-se, inclusive, com a Inconfidência Mineira. Um amor romântico enfeita a vida de Chica da Silva e de Joáo Fernandes. A presença dos filhos se torna um dado original na ficção de Paulo Amador ao construir a personagem Chica da Silva, uma vez que as mulheres negras são sempre representadas como infecundas, na maioria das obras em que elas aparecem. Já em Agripa Vasconcelos, conforme analisam Celeiro e Nascimento, (2011) Chica da Silva aparece como mãe insensível. Os cuidados maternais de Chica da Silva ficavam prejudicados, dado os seus compromissos sociais e a eterna vigilância que, por ciúmes, ela devotava a Joâo Fernandes. No entanto, a verdade era que o pouco carinho que a mãe oferecia aos filhos náo parecia sincero e os filhos estavam sempre distantes de seus afetos (VASCONCELOS, Agripa, apud CELEIRO e NASCIMENTO, 2011 , p. 247).

Anterior ao livro de Paulo Amador, em 1976, havia surgido o livro Xica da Silva, de autoria de João Felício dos Santos (1976), do qual originaria o filme de Cacá Diegues, no mesmo ano. Relembrando as consideraçóes de Beto Musa (op.cit.) sobre a ressignificação de estereótipos de negros, a imagem de Chica da Silva, sempre considerada como despudorada, ganharia uma conotação positiva. Torna-se a imagem da negra livre, sensual. Júnia Furtado (op. cit, p. 282) observa que o romance de Felício dos Santos foi escrito bem ao gosto da época, quando, na década de 70, a revolução sexual libertava a mulher de determinados comportamentos e do confinamento do lar. Ainda segundo Furtado, 
as características sensuais de Chica da Silva, inventadas por Felício dos Santos, para uma Xica, que ele traçaria com "X", ficaria eternamente colada ao mito.

O filme de Cacá Diegues, Xica da Silva, por sua vez, viria popularizar o mito de Xica da Silva, cujo nome passa ser escrito com "X", aprofundando pelas imagens a ideia de sensualidade e beleza como atributos maiores de Xica da Silva. Na maioria das vezes, no filme, Xica da Silva aparece com vestes curtas, rasgadas ou decotadas, e sempre disposta ao jogo sexual, o que leva Luiz Henrique Silva de Oliveira (2010, p. 160) a concluir que "o que parece prevalecer nos ângulos de filmagem são os atributos corporais da negra, o que, a nosso ver, denuncia a condição de "mulher-objeto presente no livro e ampliada no filme." E, mais adiante, enfatiza que a tradução da personagem para a tela se faz afirmando a imagem de Xica como "objeto sensual e sexual", devido ao foco da filmagem, que se concentra "nos atributos físicos e o privilégio da volúpia sexual”. Segundo Luiz de Oliveira, essas seriam as "características marcantes da personalidade" de Xica na visão de Cacá Diegues. O filme, para Oliveira, apresenta uma Xica do ponto de vista psicológico de "caráter inferior e degenerado". (p. 163-164)

A título de breve referência, encerramos esse tópico relembrando que, mais do que o filme, o mito de Chica da Silva, expandiu-se por meio da telenovela Xica da Silva, de Walcyr Carrasco, exibida pela Rede Manchete, em 1996, e pelo SBT, em 2005. Acrescento que a referida produção apresentou as suas virtudes e os seus malefícios, [grandes também] e que várias polêmicas sobre a novela foram levantadas na época, mas não é o nosso intuito discutir a produção televisiva neste ensaio.

Sigo o texto e nesse momento, retomando parte da pergunta inicial.

\section{Ou é a mulher que inventou o mar?}

A ficção pode tudo. Pode desmentir a História, assim como é capaz de contradizer a si própria, contestando, contrariando certa narrativa 
ficcional e apresentando uma versão diferenciada para um mesmo fato. $\mathrm{E}$, ao inventar nova ordem e novos sentidos para um mesmo evento, torna-se uma fiç̧ão outra. Portanto, pergunto: "quem foi a mulher que inventou o mar"?

O livro Chica da Silva - a mulher que inventou o mar (VIEIRA, 2001) deve ser lido desde a ilustração da capa. Uma mulher negra, com o cabelo penteado com trancinhas afro esvoaçando no ar, assim como voejam as dobras de uma longa veste colorida que lhe cobre todo o corpo. De braços abertos como se fosse flutuar nas ondas coloridas, salpicadas de peixes multicores que lhe ornamentam o traje, Chica da Silva - desenhada por outra mulher negra, a artista plástica e também de teatro, Iléa Ferraz - apresenta uma feição firme e serena. Dentre as dedicatórias da ilustradora do livro, destaco esta: "Para Zezé Motta que mostrou-me as cores da alma de Chica da Silva” (p. 4).

A Chica da Silva imaginada nas ilustraçóes de Iléa Ferraz é a mesma concebida no texto de Lia Vieira, como sendo a mulher que inventou o mar. Lendo também a dedicatória, descobrimos que a autora do texto conhece outras Chicas. Lurdinha, a mãe da escritora, recebe o primeiro oferecimento. Transcrevo a dedicatória:

Para Lurdinha, minha Abelha construtora e seus descendentes: Carlos Jorge, Luci Maria, Maria das Dores, Gerson Francisco (in memoriam), George, Karla, Carlos Pedro, Esther.

À todas mulheres negras, anônimas, Chicas em seus ideais de liberdade e resistência. (p. 4)

Continuando com o nosso intuito de cotejar o texto Chica da Silva - a mulher que inventou o mar, com a diversidade de narrativas históricas e ficcionais escritas sobre Chica da Silva, uma questão pode ser colocada. Para quê público se destina o livro que narra a história da mulher que inventou mar? Em princípio, baseada na extensão do texto, no conteúdo, na linguagem e nas ilustraçōes, a obra poderia ser classificada como infanto-juvenil. Seria, pois, possível a comparação dessa narrativa com as demais? Sim, pois o meu intento está além da 148 
comparação dos textos; desejo apreender como a condição étnica e de gênero, vivenciada conscientemente pela autora, influencia a sua criação. $\mathrm{E}$, quando me refiro à vivência consciente dessas duas condiçóes, parto das informaçóes contidas na orelha do livro, em que aparecem fotos e pronunciamentos da autora e da ilustradora como participantes de grupos de movimento negro e de mulheres negras.

A escrita ficcional do livro Chica da Silva - a mulher que inventou o mar não esquece e nem despreza os acontecimentos históricos que cercaram Chica da Silva. É um texto que, dialogando com a História e mesmo com textos ficcionais precedentes, elege outro lugar para contar a vida da heroína. Há uma profunda cumplicidade do sujeito da narração com o sujeito narrado. Diferenças sensíveis entre o discurso composto por Lia Vieira e por outros se instalam a partir da linguagem. Seguem exemplos da descrição do Arraial do Tijuco.

O Arraial do Santo Antonio do Tijuco pertencia à Comarca do Serro Frio, na longínqua Capitania das Gerais, exuberante de pedrarias e do ouro que cevava ao erário Real. [...] Nos jardins, plantas medicinais: manjerona, jurubeba, cidreira, arnica e já outras, pela cor alegre de suas flores, como a papoula, que servia também para dar brilho às botinas dos senhores. (p. 7)

Em contraste com o bater dos cascos dos animais detração, as pessoas pareciam caminhar com pés cautelosos para não acelerarem a tensão geral.

Mas os ventos do mundo continuavam a soprar... (p. 9)

Mais do que interessada em narrar a presença dos grandes vultos, como o Major Gouveia ou mesmo a família do Coronel Souza, para quem trabalha o capataz Juvêncio e escrava Maria da Costa (p. 10), apontados como os pais de Chica da Silva, a voz condutora da narrativa se volta para o povo e para os fatos do cotidiano. Diferente de todas narrativas comentadas até aqui, esta apresenta a infância de Chica da Silva, fugindo da descrição de uma infância de menina escravizada. Aqui os dotes de 
Chica da Silva nascem com ela. Não é no tempo, nos sofrimentos, que ela vai adquirir malícia, esperteza. Chiquinha é dona de uma inteligência e de uma liderança natas, pelo que sugere esta passagem:

Para as crianças [...] persistiam gestos de traquinagem. Chiquinha era líder dela. [...] entabulava negociaçôes com desembaraço. [...] Todos gostavam de Chiquinha. [...] era filha de Juvêncio, capataz da fazenda do Coronel Souza, com sua escrava Maria da Costa. [...] Tinha belos traços, um porte altivo e uma inteligência brilhante. (p. 10)

Outro dado a observar é que, desde criança, Chica da Silva almejava uma embarcaçáo e, por conseguinte, pelas águas, pelo mar. Ela "esguia, menina celebreira, inventadeira de modas! Fazia navios de casca de melancia." (p. 11) É conveniente ressaltar, que o mar criado por Chica da Silva nos textos anteriores surge a partir de um capricho, da extrema vaidade de uma mulher. No texto em questão, o mar surge como um desejo acalentado por Chica desde a infância. A menina Chiquinha também gostava de contar história que havia aprendido com sua máe. Era a griot-menina conservando o elo da corrente, repetindo a tradição, repetindo o que ouvira dos mais velhos. Uma narrativa dentro da narrativa aparece na estrutura do texto na apresentaçáo do conto "A abelha construtora", história preferida das crianças e que era narrada por Chiquinha nos dias chuvosos (p. 11-12). Uma fábula ao estilo dos contos tradicionais africanos, em que deuses e animais se comunicam.

Um aspecto a salientar no texto de Lia Vieira é que a personagem aparece descrita em suas várias etapas de vida: infância, mocidade, maturidade e morte. $\mathrm{Na}$ evolução da narrativa, que corresponde às diferenciadas fases da vida da personagem, Chica da Silva, já adulta, compreende os horrores da escravidão. Um preto velho chamado Okambi, porta-voz dos escravizados, cumpre o papel de falar à consciência de Chica da Silva. Essa função que a autora dá ao preto velho recupera no texto o papel dos anciãos, nas culturas tradicionais, como conselheiros. Ao ouvir o velho, Chica da Silva se compadece e reconhece o estado de alienaçáo em que vivia. Conversando com Nailá, uma das escravas de dentro de 
casa, ela diz: "Eu acho que andei muito tempo enganada. [...] Esqueci de minha gente. (39) A partir de então torna-se protetora dos cativos.

Na construção textual de Lia Vieira, observa-se o aproveitamento de nomes e expressóes africanas, algo que pode ser ressaltado também no texto de Paulo Amador. Entretanto, em Rei Branco, Rainha Negra, apesar de o texto ser atravessado por cantigas, versos e expressóes das culturas africanas, que às vezes são utilizadas até como uma espécie de epígrafe de determinados capítulos, não há uma fusão profunda dessas expressóes com o sentido da história que está sendo contada. No texto de Lia Vieira, ao contrário, ditos populares, expressóes do universo religioso africano e afro-brasileiro, narraçóes sucintas de mitos, assim como a própria voz mitológica, sáo procedimentos estéticos que constroem a semântica do texto. Nesse sentido, a Abelha Construtora, personagem do conto incrustado na narrativa, se apresenta como duplo de Chica da Silva e o fogo, protetor do lar, lição ensinada por Olorum à abelha, contrapóe-se ao fogo sexual imputado à imagem de Chica da Silva pelos textos tradicionais.

Com cuidado nunca visto, a narrativa é construída com uma sutileza ímpar para se referir às relaçóes amorosas de Chica da Silva. Tudo é insinuado, como nesta passagem:

- Vocês não acham que a Chiquinha tem engordado muito ultimamente? Não tem modos! Como pode o coronel Souza permitir que aquela negra conviva com sua pré-adolescente

Que descalabro!

E deu-se, assim, o início ao falatório sobre Chiquinha na cidade. [...]

Estava um dia ensolarado. [...] D. Corina sentou-se à mesa $[\ldots]$

- Coronel Sousa, o que falam de Chiquinha exige providências. [...]

- De que falas, mulher?

- Você sabe. [...]

Coronel Sousa pigarreou e, mais calmo, retrucou:

- Vou por um fim nisso 
Assim Chiquinha, agora Chica, mudouse da casa do coronel Souza para a casa do intendente Muniz.

Ali teve seu primeiro filho Simão e logo seguiu-se Cipriano, o segundo. (p. 19)

A descrição do momento em que o casal se vê pela primeira vez coloca a relação dos dois nos moldes de um amor romântico. Aqui também há uma contraposição ao estado de quase desespero sexual, que acomete Chica da Silva e João Fernandes, no primeiro instante em que se olham, de acordo com outras narrativas já sacramentadas. Eis a descrição de Lia Vieira:

Estavam em meio ao pomar, sob a copa de velhas mangueiras, quando deles se aproximou Chica. [...] Trouxe para o ar, um cheiro adocicado de jasmim e aloés. Com modos mansos e elegantes, fez uma reverência ao visitante. $\mathrm{O}$ olhar penetrante, dentadura belíssima e o altivo porte de rainha. [...] Chica começou a povoar os sonhos do contratador que, em vão, tentou sufocar a sua paixão.

Quanto mais buscava esquecê-la, mais a imagem corporificava-se em seus pensamentos.

Também ele povoava os sonhos de Chica, a quem a saudade torturava o coraçáo. (p. 25-26)

O primeiro encontro amoroso de Chica da Silva e de João Fernandes recebe, da mesma forma, um tratamento especial na descrição da cena, distinguindo-se de todos os relatos anteriores. A voz que conduz a narrativa revela os sentimentos do contratador, João Fernandes de Oliveira, quando,ao entrar no quarto de Chica da Silva, depara com "uma deusa de açafrão, a amante de seus sonhos". E fixando "os olhos cobiçosos na imagem resplandecente. Os coraçōes acelerados tremeram em pulsaçôes de marfim e ébano, que se prolongaram até quando a cotovia anunciou o amanhä" (p. 31). Observa-se no interior da frase o aproveitamento da antítese "marfim e ébano", representada pelos corpos 
dos dois. A metáfora de um pássaro proclamando o amanhã pode ser lida como o futuro amoroso dos dois sendo pré-anunciado. A descriçáo do corpo de Chica da Silva como "uma imagem resplandecente" e a enunciaçáo anterior desse corpo como sendo o da "deusa de açafrão" quebra, ou melhor, abranda o sentido da afirmaçáo "fixou os olhos cobiçosos", indicativa do desejo e do encontro sexual do dois, condiçóes marcantes na vida do casal e que o texto náo podia se esquivar de narrar. Ressalto, ainda, que há uma primorosa descrição da ambiência na qual se dá o primeiro encontro do casal, o quarto de Chica da Silva. Lemos no texto que o aposento ficava situado entre dois jardins e que tinha espelhos, cortinas de chiffon com tons púrpura e violeta. E "havia flores, muitas flores" (p. 30).

No plano da ilustraçáo, há uma imagem de Chica da Silva com uma criança no colo, enquanto que uma menina, filha também dela, ainda pequena, toca o bebezinho que a mãe carrega. Atrás da mãe, aparecem duas mulheres, uma delas com outra filha de Chica da Silva. Esta imagem compóe um dos desenhos mais belos do livro. Uma cena focalizada em uma mãe negra com a sua descendência, uma representação raramente colocada na literatura brasileira.

A voz narrativa, acompanhando o amadurecimento de Chica da Silva ao longo do tempo, diz que: "A passagem dos anos dera à Chica o aspecto de uma jóia rara" e zelosamente ela cuidava de sua numerosa prole: Simão, Cipriano, João Fernandes Filho, Francisca, Luísa, Rita, Antonia, Joaquim, Ana Quitéria, Helena, fazendo imperar a paz em seus domínios. (p. 43).

O texto, como já foi afirmado anteriormente, não ignora a história de Chica da Silva como um evento ancorado na História do Brasil, mas reescreve o fato a partir de outra perspectiva, parodiando, talvez, com o que foi sido concebido sobre Francisca da Silva de Oliveira. E se distancia em contraste com outras ficçôes que têm a heroína negra como mote inspirador. $\mathrm{O}$ elemento que, sem dúvida alguma, mais institui a diferença textual da criação de Lia Vieira, dos demais discursos, é o tratamento que a escritora dá ao episódio do mar, mandado construir pelo contratador, atendendo aos desejos da mulher amada. A longa 
citação se faz necessária; no texto impera um ponto de vista diferenciado quanto ao entendimento do desejo de Chica da Silva em ter uma réplica do mar em sua casa. O que, para muitos, foi interpretado como capricho, extravagância, excentricidade de Chica da Silva, a narrativa de Lia Vieira traduziu como um "projeto mirabolante", em que a mulher, duplo da "abelha construtora", inventava pela força de seu desejo, o mar, inconcebíveis águas, no Arraial do Tijuco. Eis a passagem:

Assentada em sua cadeira de palhinha [...] a Abelha Construtora era hábil e eficiente no sentido da intuição e dos sonhos que acalentava.

E numa dessas tardes mornas, confidenciou a João Fernandes de Oliveira, a ideia de ter o seu mar.

- O futuro está aqui, falta-nos o encanto e o poder das águas. Como voluntariosa e predestinada, insistia: - Sou daquelas feita para exceçôes, não para as regras.

Este foi sem dúvida o mais ousado desafio em seus sonhos de liberdade: o mar de Chica.

Joâo Fernandes e Oliveira [...] cedeu a mais este projeto mirabolante de Chica, a quem o querer e o coração não punha limites. [...]

Astuciosa naquilo que acreditava, Chica fez contratar armadores portugueses [...] que em muralhas fixaram um braço do rio.

Era febril a engenhosidade em torno da obra faraônica, da magnitude do projeto. Era a vida configurada na tela da artista. $O$ êxtase da realização. (p. 44) (sem grifos no original)

E mais do que o entendimento de que a construção de um mar para Chica da Silva, se tratava da "vida configurada em arte" (p. 47), a narrativa indica que esse era o mar africano pelas saudaçôes com que foi recibo: "As exclamaçóes subiam de todas as partes: Iemanja, Olokum, Mukinã, Dandalunda” (p. 47). Mais do que isso, era o mar africano, pelas saudaçôes com que foi recebido: "As exclamaçôes subiam de todas as partes: - Iemanjá, Aioká, Olokum, Mukinã, Dandalunda.” (p. 47). 
Chica da Silva, a mulher que inventou o mar, sabia bem o significado das águas de Kalunga para o seu povo. A celebração das águas instaladas conferia à "Rainha Negra" o seu apogeu. E ela "fez seu povo navegar com ela. Quando a noite iluminou as águas, ela sabia que não existiria em lugar nenhum do mundo, outro mar como aquele, no seu reinado o fascínio era táo grande como o poder" (p. 47).

Assim como no Romanceiro da Inconfidência, na narrativa de Lia Vieira, Chica da Silva também prevê as armadilhas do Conde de Valadares sobre o contratador João Fernandes, pois é detentora de uma força intuitiva e premonitória, acrescida de uma certa argúcia. $\mathrm{O}$ dado novo é que essas características de Chica aparecem oriundas, filiadas das formas de uma sabedoria africana. Uma canção em versos, entoada por um menino, livra Chica da Silva de morrer envenenada por pudim de claras enviado por uma das damas da cidade, "D. Sophia Ítala Fausta", frequentadora da mansão de Chica. Nota-se que a falsidade dessa mulher aparece aludida em seu próprio nome. Um dia, "ao retornar da reza vespertina", Chica da Silva ouve essa canção: "Olokum, Olokum!/ Se hoje te trouxerem um prato de arroz, recusa-o/Olokum/ Ele contém veneno, Olokum/A terra que estás comendo, Olokum, te comerá Olokum”. Essa passagem oferece, não só, uma visão de Chica da Silva inserida em um fundamento negro-africano, como também a subversão de uma postura religiosa da fé, uma vez que ela voltava de uma prática católica e finaliza esse ato com um gesto originário de sua ancestral fé. Lemos que, ao chegar a casa, encontra um pudim de claras enviado por D. Sophia e que, lembrando-se da cançáo, deposita o prato no formigueiro e "cuspiu três vezes na direçáo do Arraial". (p. 51). Outro momento que traz explicitamente o imaginário, ou melhor, uma postura calcada em uma visão africana, é a valorização do sonho, fenômeno intensamente valorizado, em diversas culturas tradicionais africanas, como sinal de algo vai acontecer. A premoniçẫo, de que o Conde de Valadares arquitetava o fim de João Fernandes junto à corte, foi comunicada à Chica da Silva por meio de um sonho. Em uma determinada noite "Chica teve pesadelos angustiosos, a visão de uma nau sem leme em noite de tempestade” (p. 52). Essa imagem de uma 
nau sem leme pode ser também relacionada ao signo do navio e seus desdobramentos na história da diáspora africana.

Com relação aos dias finais de Chica da Silva, enquanto os outros relatos primam em descrever a decadência da personagem, a narrativa de Vieira insiste na afirmativa da dignidade de Chica da Silva, embora náo negue a solidão da mulher: "Os dias rolavam tristes. Chica não era mais a mulher majestosa de outros tempos, embora conservasse o porte altivo e a liderança" (p. 56. [grifos meus]).

A morte de Chica da Silva recebe um tratamento também bastante original. A personagem celebra a própria morte com uma canção, que é respondida por uma de suas fiéis acompanhantes. $\mathrm{O}$ canto e a dança, na hora desse crucial momento de vida, assim como nas cerimônias fúnebres, estão presentes em várias culturas africanas e no Brasil. O ritual do axexê, dispensado às mães e pais de terreiros, atualizam parte de uma memória africana entre nós. Os momentos finais de Chica da Silva estão assim descritos: "Pela porta entreaberta [Nailá] observou na Sinhá as feiçōes do rosto envolvidas em uma beleza de juventude recuperada". Chica da Silva tinha nas mãos "o baú de flandres, relicário de sortilégios em pedras preciosas, que manuseava" e sussurrava uma "suave música" cujos versos eram: "O rio corre para o mar/lua veio anunciar maré vazante/carrega saudade pra lá/carrega quizilá pra lá/ Ê Girê, o Girá/ Me leva Girá, para o fundo do mar." Ao que a escrava acompanhante, "com os olhos de quem já tinha visto de tudo" apreendeu "o encantamento" da hora, quando "todas as velas enfunadas ao vento chegaram ao porto." Nesse momento Naila cantou em surdina: Iemanjá sobá, sobá mieiê/ Sobá mieiê, ô doía, sobá mieiê” (p. 59). Nota-se, no texto, a recuperação de uma origem africana, de um retorno simbólico ao ventre materno para a personagem. Uma Chica da Silva, que "usava agora tranças africanas"(p. 56), não mais as cabeleiras europeias e que tinha transcorrido grande parte de sua vida presa a um esforço de construção de uma aparência e de um estilo de vida europeu - como uma tática possível de sobrevivência, em meio à sociedade escravocrata da época - retorna simbolicamente ao 
ventre materno na hora de sua morte. As águas de kalunga guardam os mortos, visão cosmogônica, que pode ser recolhida em culturas africanas, aportadas em toda as Américas. Chica da Silva é acolhida por Iemanjá, a Rainha do Mar, Orixá reconhecida em terras brasileiras.

Conforme foi observado anteriormente, o livro Chica da Silva, a mulher que inventou o mar parece se destinar a um público infantojuvenil, embora a sua ficha catalográfica incompleta não traga nenhuma indicação nesse sentido. O que se quer, entretanto argumentar, é que, independente do público, ao qual a obra se destina, é perceptível a intenção e o esforço da autora em criar outro imaginário em torno da personagem. A narrativa de Lia Vieira pode ser lida como uma prática discursiva travada no campo de uma batalha simbólica, onde aqueles/as, que sempre foram representados pela autoridade/autoria da cultura hegemônica, lutam para instituir uma representatividade própria. Passeando pelo que já foi inventado sobre Chica da Silva, a escritora escolhe outro lugar de enunciação, opta por um novo lócus para a produção de sentido de seu discurso. Escrevendo um texto a partir de outro ponto de vista, o de uma mulher negra inserida no movimento social negro e de mulheres negras, Lia Vieira, assim como a ilustradora do livro, Iléa Ferraz, concebem uma contra-narrativa a tudo que foi veiculado sobre Francisca Maria de Oliveira. A opção consciente das duas artistas, uma da palavra, outra das artes plásticas, se inscreve no proposto por Homi Bhabha (1998, p. 321) acerca da poesia do colonizado. Para ele, o discurso poético do colonizado não só encena o "direito de significar", como também questiona o direito de nomeação que é exercido pelo colonizador, sobre o próprio colonizado e seu mundo. Exercendo o direito de significar a si própria, a narrativa, não a da Chica-que-manda, mas a da mulher que inventou o mar, pode ser lida como um discurso literário em busca de uma nova identidade para as mulheres negras.

[Texto recebido em maio de 2013 para compor a corrente edição especial] 


\section{Referências}

ALVES, Miriam. Mahin Amanhâ. In: Cadernos Negros. v.9 - Poemas - São

Paulo, Edição dos Autores, (Org.) Quilombhoje, 1986.

AMADOR, Paulo. Rei Branco, Rainha Negra. Belo Horizonte: Editora Lê, 1990.

BHABHA, Homi K. O local da cultura. Tradução Myriam Ávila, Eliana Lourenço de Lima Reis e Gláucia Renate Gonçalves. Belo Horizonte: UFMG, 1998.

CARRASCO, Walcyr, Xica da Silva. Rio de Janeiro: Manchete, 1996, São Paulo: SBT, 2005.

CELEIRO, Regina Leite Lima e NASCIMENTO, Vinicius Amarante. Chica que manda: História e Literatura no mundo das representações de Agripa Vasconcelos. História e Perspectivas, 45, jul:/dez, 2011.

DIEGUES, Carlos. (Dir) Xica da Silva. Rio de Janeiro:

Embrafilme, 1976.

FURTADO, Junia Ferreira. Chica da Silva - o outro lado do mito. São Paulo: Companhias das Letras, 2003.

GAMA, Luis. Carta a Lúcio de Mendonça. In: DUARTE, Eduardo de Assis. (Org.) Literatura e Afrodescendência no Brasil: antologia crítica. Vol. 1,. Belo Horizonte: Editora UFMG, 2011, p.131.

GONÇALVES, Ana Maria. Um defeito de cor. Rio de Janeiro: Record, 2006.

MEIRELES, Cecília. Romanceiro da Inconfidência. São Paulo: Círculo do Livro, 1975. 
MUSA, Beto. Estereótipos de negro na literatura brasileira: sistema e motivação histórica. Estudos Afro-Asiáticos, n. 16, Rio de Janeiro: Centro de Estudos Afro-Asiáticos, 1989.

OLIVEIRA, Luiz Henrique Silva de. Xica da Silva: tradução intersemiótica e construção da protagonista. In: DUARTE, Constância Lima, DUARTE, Eduardo de Assis, ALEXANDRE, Marcos Antonio. (Org.). Falas do Outro - literatura, gênero, etnicidade. Belo Horizonte: Nandyala, NEIA, 2010.

PRIORE, Mary Del. A mulher na Historia d Brasil, São Paulo: Contexto, 1999.

SANTOS, Joaquim Felício dos. Memórias do Distrito Diamantino. Petrópolis: Editora Vozes Ltda., 1978.

SANTOS, João Felício dos. Xica da Silva, Rio de Janeiro: Civilização Brasileira, 1976.

SOUZA, Joaquim Silvério. Sitios e personagens históricos de Minas Gerais. Belo Horizonte: Imprensa Oficial, 1988.

VASCONCELOS, Agripa. Chica que manda. Belo Horizonte: Itatiaia, 1966.

VIEIRA, Lia. Chica da Silva - a mulher que inventou o mar. Rio de Janeiro: OR Produtor Editorial Independente, 2001.

\section{Chica who bosses or woman who invented the sea?}

Abstract: Going through the records of the official Brazilian history, it is possible to observe the lack of reports highlighting the performance of black women in several episodes of our national history. A singular case is that of Francisca da Silva de Oliveira who, upon reaching the status of "historical object", becomes, nevertheless, a victim of a deeply stereotypical narrative. The first historical accounts of Chica da Silva are always determined by a male and white viewpoint. These accounts appear reedited by literary, movie and television 
productions which, through time, are emerging about this black character that marked the history of Minas Gerais and of Colonial Brazil. The present paper brings some consideration around the creation and recreation of the image of Chica da Silva based on historical and literary texts. It is possible to affirm that there is some consistency between the historical and literary representations. In both modes, most of the time, the imaginary of black women being seductive only by their sexual physical endowment prevails. And, to compare with the various versions created to Chica da Silva, I decided to bring the reading of the Afro-Brazilian fictional text, Chica da Silva - a mulher que inventou o mar (Chica da Silva - the woman who invented the sea), written by Lia Viera, seeking to find distancing and/or approximations between this Afro-Brazilian creation and previous narratives about Francisca da Silva de Oliveira.

Keywords: History. Literature. Representation. Black woman.

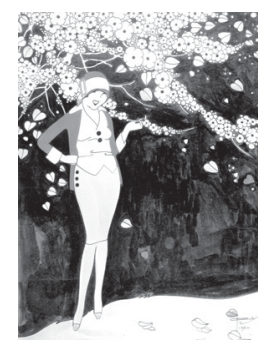

